\title{
In two decades of awards, how many for innovation? The role of diffusion within the Enap Awards
}

\author{
ELISÂNgela DoURAdo ARISAWA ${ }^{12}$ \\ MARINA FIGUEIREDO MOREIRA ${ }^{1}$ \\ ${ }^{1}$ Instituto Nacional de Estudos e Pesquisas Educacionais Anísio Teixeira (INEP), Brasília - DF, Brasil \\ 2 Universidade de Brasília (UnB) / Programa de Pós-Graduação em AdMinistração, Brasílıa - DF, Brasil
}

\begin{abstract}
This study maps the dimensions and variables that explain the diffusion of innovation in public services and test their applicability in the case of the ENAP Awards. The article presents a literature review that supports a conceptual explanatory theoretical model for innovation diffusion in public services, for future use in an empirical test. The model consists of two dimensions and ten variables. In the dimension organization characteristics, the variables are resource slack, flexibility and decentralization, alignment between high-management, managers, nad leaders, inter and intra-organizational communication, risk-taking capacity, and organizational learning/knowledge. As for the dimension innovation characteristics, the variables are adaptation/reinvention, complexity, relative advantage, and compatibility). The occurrence of these dimensions and their variables were tested through the perception of five members of the external review team of the ENAP Awards (called 'Specialists'). Semi-structured interviews were conducted with the specialists. The research used content analysis and-pre-set categories to examine the interviews and documents related to the Awards. The specialists recognized and typified the dimensions and variables, confirming the applicability of the theoretical dimensions in the public services. However, some variables (such as "Risk-taking Capacity") manifested differently from the way the original theory introduced them.
\end{abstract}

Keywords: Diffusion of innovations. Innovation in public services. Diffusion of innovations in public services.

\section{Duas décadas de premiação, quantas de inovação? O papel da difusão no Prêmio Enap}

\section{Resumo}

Este estudo mapeia dimensões e variáveis explicativas da difusão da inovação em serviços públicos e testa sua aplicação ao caso do Prêmio Enap. Por meio de revisão de literatura, compõe-se um modelo teórico conceitual explicativo da difusão da inovação aplicável a serviços públicos para posterior teste empírico. Esse modelo tem 10 variáveis, distribuídas em 2 dimensões: 1) Características da organização - composta por a) sobra organizacional, b) flexibilidade e descentralização, c) alinhamento entre alta administração, gerências e líderes, d) comunicação inter e intraorganizacional, e) capacidade de assumir riscos e f) aprendizagem/conhecimento organizacional; e 2) Características da inovação composta por a) adaptação/reinvenção, b) complexidade, c) vantagem relativa e d) compatibilidade. Testa-se a manifestação das dimensões e suas variáveis na percepção de 5 membros da avaliação externa do Prêmio Enap, aqui denominados especialistas. Foram realizadas entrevistas semiestruturadas com esses especialistas e seus relatos, junto a documentos associados ao Prêmio Enap, foram submetidos a análise de conteúdo com categorias definidas a priori. Os resultados apontam que as 10 variáveis das 2 dimensões foram reconhecidas e tipificadas pelos especialistas, confirmando a aplicabilidade das dimensões teóricas ao objeto dos serviços públicos. No entanto, algumas das variáveis, a exemplo da "capacidade de assumir riscos", têm manifestação diversa da apresentada na teoria original.

Palavras-chave: Difusão da inovação. Inovação em serviços públicos. Difusão da inovação em serviços públicos.

\section{Dos décadas de premiación, ¿cuántas de innovación? El papel de la difusión en el Premio Enap}

\section{Resumen}

Este estudio mapea dimensiones y variables explicativas de la difusión de innovaciones en servicios públicos y prueba su aplicación al caso del Premio Enap. Por medio de revisión de literatura, se compone un modelo teórico conceptual explicativo de la difusión de innovaciones aplicable a servicios públicos para posterior prueba empírica. El modelo está compuesto por dos dimensiones y diez variables: i) Características de la organización (dimensión compuesta por las variables Sobra organizacional; Flexibilidad y descentralización; Alineamiento de la alta administración, gerencias y líderes; Comunicación inter e intraorganizacional; Capacidad de asumir riesgos y Aprendizaje/conocimiento organizacional) y ii) Características de la innovación (dimensión compuesta por las variables Adaptación/reinvención; Complejidad; Ventaja relativa y Compatibilidad). Se prueba la manifestación de las dimensiones y sus variables en la percepción de cinco miembros de la evaluación externa del Premio Enap aquí denominados especialistas. Se realizaron entrevistas semiestructuradas con estos especialistas y sus relatos, con documentos asociados al Premio, y se sometieron a análisis de contenido con categorías definidas a priori. Los resultados indican que las dos dimensiones y las diez variables fueron reconocidas y tipificadas por los especialistas, lo que confirma la aplicabilidad de las dimensiones teóricas al objeto de los servicios públicos. Algunas de las variables, a ejemplo de "capacidad de asumir riesgos", sin embargo, poseen manifestación diversa de la presentada en la teoría original.

Palabras clave: Difusión de innovaciones. Innovación en servicios públicos. Difusión de innovaciones en servicios públicos. 


\section{INTRODUCTION}

Since 1996, the Brazilian National School of Public Administration (Enap) has selected and conceded awards to cases of innovation on public services that achieve a level of organizational highlight, either locally or nationally. This is a policy that aims to stimulate innovation implemented on public services that have attained a high level of notoriety and that has already awarded, for example, the Federal Administration Integrated System (Siafi), the Evaluation and Monitoring System, developed by the Ministry of Social Development (MDS) and, on the education field, the Basic Education Evaluation System (Saeb). Innovation policies such as this one are based on the premise that innovative cases must be recognized and publicized to potential new adopters, as a strategy to achieve a desirable level of dissemination (ROGERS, 1983). In theoretical terms, this relates to the diffusion of innovation, the confirmatory step towards an effective dissemination and the creation of impact to a newly implemented innovation - the typical case awarded by Enap. This study aims particularly to investigate the explicative dimensions and variables related to the diffusion of innovation in public services that apply to the Enap Awards.

We know that the diffusion of a promising technical change (DOSI, 2005) cannot be granted within an ex-ante frame. However, it remains crucial so such change can be typified as innovation. This is the inherent challenge when it comes to innovation encouragement policies such as the Enap Awards: how to establish a priori criteria in order to characterize an ongoing innovation, with promising, however uncertain, diffusion capacity? Even though the diffusion of innovation premise has its origins on Schumpeter, referring to one step of the creative destruction process (SCHUMPETER, 2017), diffusion has only become an isolated object of study during the decade of 1980, with Rogers (1983), who focuses on the phenomenon of the adoption of innovation by an individual who was influenced by communication channels. Since then, theory has achieved progress on the proposition of theoretical models on diffusion. However, their applicability to public services remains a gap. Thereby, after two decades of the Enap Awards, one question gains prominence: how can we assess the effective level of innovation of the awarded cases, that is, how can we diagnose the diffusion of such innovation on public services? This is the gap to which we dedicate this study.

Mapping the diffusion of innovation in services demands the adoption of a theoretical perspective in order to understand innovation in light of the service sector's peculiarities. Until the 1990s, all literature dedicated to innovation in services consisted of conceptual and methodological transposition originating in the manufacturing industry, with researches limited to the technological aspects of innovation and its diffusion, especially on the impact of technological innovation on services (MILES, 2008; HOWELLS, 2010; METCALFE and MILES, 2012). Through the las two decades, researchers have striven to build a specific approach for innovation in services, without neglecting its own characteristics, such as the integrative approach expressed by Gallouj and Savona (2010).

Regarding its manifestation, beginning on the 1990s, innovation has become part of the discussions regarding public administration in the context of the demand for a modern public machine (FARAH, 2006), guided by the principles of the new public management and by the pursuit for administrative efficiency. This way, it is argued that innovation should be institutionalized by the public sector in order to cut costs within the administration and to ensure that the public services are provided in a satisfactory manner within the budgetary limits (ALBURY, 2005). Thus, we face the following issue: the State must innovate and, of course, promote and reach the diffusion of its own innovations, but the theories that verse on public administration do not present themselves as a theoretical summarization that could explain the dimensions and variables involved on the diffusion of such innovations. For that reason, we have chosen as research question for this study:

- Which theoretical criteria could substantiate the evaluation of the diffusion of innovation on public services within the initiatives awarded by Enap?

The first edition of the Awards on Innovation in the Federal Public Administration, which was organized by Enap in 1996 (now entitled Award on Innovation in the Public Sector), became part of the discussions on the State's administrative reform, which aimed to modernize the State, guiding it towards efficiency and result-attainment (BRESSER-PEREIRA, 2000). The creation of the Awards was a response to a demand for State modernization, in the same way as the upcoming editions reflected the management trends currently in vogue. According to Ferrarezi, Amorim and Tomacheski (2010), from 1996 to1998 the 
Awards aimed to stimulate innovation that fostered the public sector's administrative reform. However, the contest started using stricter selection criteria and offering more attractive rewards only in 1999.

In order to promote a critical discussion on the criteria which were established for granting the Enap Awards and on its capacity to diagnose not only the innovation itself, but also its potential for diffusion, this research has performed an exhaustive review of both national and international literature, with the intention of summarizing the theoretical factors that explain the diffusion of an innovation applicable to public services. We propose a theoretical-conceptual model tested by Enap specialists. Thus, we can highlight the two main contributions made by this study to the literature: 1) proposing a theoretical-conceptual model that summarizes the state of art of the factors that explain the diffusion of an innovation applicable to public services; and 2) the empirical test of the manifestation of each theoretical dimension through the understanding of specialists that participate on the selection of the cases awarded by Enap.

\section{DIFFUSION OF INNOVATION}

In order to summarize the state of art for the diffusion of innovation in face of its application to public services, this study searched for references at the Capes Periódicos Web Portal and at the SPELL and ProQuest databases that were associated to the diffusion of innovation in services or to the diffusion of innovation in public services using the following keyword combinations: 1) "diffusion" or "adoption" or "implementation" or "sustainability" or "institutionalisation" or "routinisation"; 2) "innovation" or "innovations"; e 3) "public services" or "public sector" or "services".

The results led to the selection of two studies that, in this case, compose the foundation of the summarization. The studies consist of systematic reviews of the literature, conducted by Greenhalgh, Robert, Macfarlane et al. (2004), on innovation in healthcare services, and by por De Vries, Bekkers e Tummers (2016), on innovation in the public sector. The firsts study proposes a systematic review of the literature on the multiple influences in the adoption and assimilation of innovation in healthcare services and was later supplemented by Greenhalgh, Barton-Sweeney and Macfarlane (2013). The nature of this model, which is focused on a sectoral manifestation with a high level of specificity, limits its general applicability to public services - for this reason, we understand that it presents itself more as a model for the diffusion of innovation in healthcare services than as a model for the diffusion of innovation in services that can be used in other contexts.

The second study consists of a systematic review of the literature on innovation in the public sector. Although the authors claim that research often addresses the diffusion of innovation, diffusion, as a stage, is little explained in its own model. This seems to be a common understanding in the literature: diffusion occurs, but always in an unmapped or unexplained way in the light of theoretical models. Thus, we justify the research gap explored in this subject: to propose a theoretical model capable of specifying the variables that explain the diffusion of innovation in public services. To do so, this study considers the two cited papers and uses the original literature on innovation to seek additional manifestations related to the diffusion stage to be incorporated into the model proposed in this study. Box 1 summarizes the original innovation concepts and their approach to the diffusion of innovation. These concepts reveal the crucial character of the diffusion stage associated with the manifestation and confirmation of innovation. 
Box 1

\section{Innovation concepts that integrate aspects related to diffusion}

\begin{tabular}{|c|c|c|}
\hline Innovation concepts & Authors & Emphasized aspects of diffusion \\
\hline $\begin{array}{l}\text { Diffusion is fundamental to innovation, so that it may } \\
\text { achieve all of its potential for economic change. On the } \\
\text { "invention / innovation / diffusion" trilogy, the linear } \\
\text { comprehension of the process positions diffusion as } \\
\text { the last part of the innovative process. }\end{array}$ & Schumpeter (1985) & $\begin{array}{l}\text { Emphasis on the diffusion of technology. } \\
\text { The classic Schumpeterian view lead to } \\
\text { the evolutionary or neo-Schumpeterian } \\
\text { perspective that deals with diffusion on } \\
\text { economic studies. }\end{array}$ \\
\hline $\begin{array}{l}\text { Idea, practice or object perceived as new by an individual } \\
\text { or a different adoption unit. }\end{array}$ & $\begin{array}{l}\text { Rogers (1983); Walker, } \\
\text { Damanpour and } \\
\text { Devece (2010); Borins } \\
\text { (2014); Walker (2014) }\end{array}$ & $\begin{array}{l}\text { Emphasis on the adopter. Regarding Rogers } \\
\text { (1983), on the adopting individual. Rogers } \\
\text { (1983) performs the revision and theoretical } \\
\text { generalization of empirical researches on } \\
\text { diffusion within the most diverse areas of } \\
\text { knowledge. }\end{array}$ \\
\hline $\begin{array}{l}\text { Innovation is a specific form of change: it is either a } \\
\text { discontinuous change or a radical rupture with the past or } \\
\text { the introduction of new elements to the public service-- } \\
\text { in the form of new knowledges, a new organization and/ } \\
\text { or new management or process tools, which represent } \\
\text { a discontinuity in relation to the past. }\end{array}$ & $\begin{array}{l}\text { Rogers (1983); } \\
\text { Brown and Osborne } \\
\quad(2012)\end{array}$ & $\begin{array}{l}\text { Emphasis on the continuous and adaptive } \\
\text { change on the organizational and individual } \\
\text { level. The change must be continuously } \\
\text { moving through an induction-uncertainty- } \\
\text { transformation-routinization cycle. }\end{array}$ \\
\hline $\begin{array}{l}\text { Producing or adopting new ideas, objects or practices. } \\
\text { The production creates a result, which could be either a } \\
\text { product, a service or a practice that at least a determined } \\
\text { organizational population recognizes as novelty, while the } \\
\text { adoption consists of using either a product, a service or } \\
\text { a practice that is new to a determined unit of adoption } \\
\text { - individual, team or organization. }\end{array}$ & $\begin{array}{l}\text { Rogers (1983); Walker, } \\
\text { Damanpour and } \\
\text { Devece (2010) }\end{array}$ & $\begin{array}{l}\text { Emphasis on the adoption and not only } \\
\text { on the generation of innovation. It also } \\
\text { highlights the organizational scope and } \\
\text { the expansion of the unit of adoption from } \\
\text { individual to team or organization. }\end{array}$ \\
\hline $\begin{array}{l}\text { New or improved services, products, processes and } \\
\text { methods. Provided they are new to the organization, } \\
\text { they may have been developed by other organizations. }\end{array}$ & $\begin{array}{l}\text { OCDE (2005); Bloch } \\
\text { (2010); Hughes, Moore } \\
\text { and Kataria (2011) }\end{array}$ & $\begin{array}{l}\text { Emphasis on the adoption and not only on } \\
\text { the generation of innovation. The idea of } \\
\text { "improvement", along with that of novelty, } \\
\text { is accepted. }\end{array}$ \\
\hline $\begin{array}{l}\text { Developing and implementing a new product, service, } \\
\text { process, technology, policy, structure or administrative } \\
\text { system. }\end{array}$ & $\begin{array}{l}\text { Damanpour and } \\
\text { Schneider (2006); } \\
\text { Walker (2007); } \\
\text { Damanpour, Walker e } \\
\text { Avellaneda (2009) }\end{array}$ & Emphasis on the implementation. \\
\hline $\begin{array}{l}\text { Innovation is the implementation of a new or significantly } \\
\text { improved product (either a good or a service), or a process, } \\
\text { or a new marketing method, or a new organizational } \\
\text { method in business practices, workplace organization, } \\
\text { or external relations. }\end{array}$ & OCDE (2005) & $\begin{array}{l}\text { Emphasis on the implementation, on the } \\
\text { idea of "improvement" along with that of } \\
\text { novelty, and in the organizational scope. } \\
\text { In this classification, products cover both } \\
\text { goods and services. }\end{array}$ \\
\hline
\end{tabular}

Source: Elaborated by the authors.

\section{Diffusion of innovation in public services}

The models of Greenhalgh, Robert, Macfarlane et al. (2004) and de Vries, Bekkers and Tummers (2016) focus on sectoral analyses and, for that reason, do not consider diffusion from an inter-organizational or organizational perspective (HARTLEY, 2016). Therefore, the theoretical-conceptual model aims to allow the analysis of the diffusion of innovation in public services under an organizational perspective regarding the innovation's assimilation and sustainability, in order to make it possible to guide the evaluation of the occurrence of the diffusion in public organizations. Thus, we assume that the experiences within the public sector can offer new elements for the consolidation of verification parameters and criteria for the diffusion. The multilevel approach proposed by Greenhalgh, Robert, Macfarlane et al. (2004) is especially interesting for the purpose of this research for it presents different analytical perspectives of diffusion, not only in reference to the individual, but also 
suggesting an organizational approach for the phenomenon. For this purpose, we also bring to bear the formulations made by authors that deal with the organizational perspective, such as Meyer and Goes (1988) and Van de Ven, Polley and Garud (2008), which use the term "assimilation" in replacement to "adoption." The assimilation would then comprehend the stages that would lead to the implementation of an innovation.

Among the main contributions made by the works of Trisha Greenhalgh and her collaborators, her terminology stands out. Thus, we can point out the distinction between the term adoption, used for the investigation of the phenomenon of diffusion in the individual, and the term assimilation, for the investigation of the same phenomenon from an organizational perspective. In fact, the proposition of the metanarrative method in a systematic review (GREENHALGH, ROBERT, MACFARLANE et al., 2004) for the analysis of diffusion makes a more significant contribution to the consolidation of a theoretical-conceptual status diffusion in innovation, since this method approaches topics with different concepts by different groups of researchers to build a comprehensive narrative that gives prominence to the multidisciplinary perspective. This aspect, by the way, is critical for the construction of the model proposed in this research, which turns to public services that are naturally multidisciplinary in their manifestations, given the wide range of issues associated with the Enap Awards cases.

We chose the stage distinction validated by Greenhalgh, Robert, Macfarlane et al. (2004) - initiation / development / implementation -, followed by sustainability, a differentiation that can be characterized by routinization (GREENHALGH, ROBERT, MACFARLANE et al., 2004; GREENHALGH, BARTON-SWEENEY and MACFARLANE, 2013) e institutionalization (ALBERTI and BERTUCCI, 2006; GREENHALGH, BARTON-SWEENEY and MACFARLANE, 2013). Besides the theoretical frame already presented, the works of Rogers (1983), Sugarhood, Wherton, Procter et al. (2014), for their review of the variables originally listed by Greenhalgh, Robert, Macfarlane et al. (2004), Greenhalgh, Barton-Sweeney and Macfarlane (2013) and Farah (2006) for their manifestation in public services. In addition, the dimensions and variables listed by Damanpour and Schneider (2008), Hartley and Benington (2006), Hartley and Rashman (2007), Rashman, Withers and Hartley (2009), Hartley (2016), Brown), Brown and Osborne (2013) are also part of the model. The contributions of each work and their classification are presented in Box 2. 


\section{Box 2}

Dimensions and variables that explain the diffusion of innovation on public services

\begin{tabular}{|c|c|c|c|}
\hline $\begin{array}{l}\tilde{n} \\
\frac{0}{n} \\
\frac{c}{d} \\
\frac{\varepsilon}{0}\end{array}$ & Variables & Definitions & Authors \\
\hline \multirow{6}{*}{ 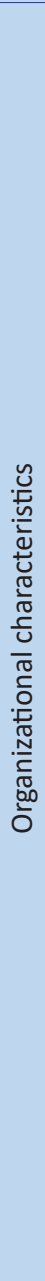 } & Slack resources & $\begin{array}{l}\text { The organization's resources that exceed the minimum requirements } \\
\text { demanded to keep its operations (DAMANPOUR, 1991). }\end{array}$ & $\begin{array}{l}\text { Damanpour (1991); Greenhalgh, } \\
\text { Robert, Macfarlane et al. (2004); } \\
\text { Walker (2006); De Vries, Bekkers } \\
\text { and Tummers (2016). }\end{array}$ \\
\hline & $\begin{array}{l}\text { Flexibility and } \\
\text { decentralization } \\
\text { in the organization }\end{array}$ & $\begin{array}{l}\text { The adaptive and flexible nature of the organizational structure, as } \\
\text { well as the capability held by both the structure and the organizational } \\
\text { processes to embrace decentralized decisions, reinforces the success } \\
\text { of the implementation and increases the probability of routinization. } \\
\text { (GREENHALGH, ROBERT, MACFARLANE et al., 2004). }\end{array}$ & $\begin{array}{l}\text { Rogers (1983); Van de Ven, Polley and } \\
\text { Garud (2008); Greenhalgh, Robert, } \\
\text { Macfarlane et al. (2004). }\end{array}$ \\
\hline & $\begin{array}{l}\text { Alignment between the } \\
\text { higher administration, } \\
\text { mid-level management } \\
\text { and involved leaders }\end{array}$ & $\begin{array}{l}\text { The support given by the higher levels of the administration, the acting } \\
\text { of those who defend innovation in the implementation process and the } \\
\text { continuous commitment enhance the implementation and routinization } \\
\text { process. The alignment between the higher administration, mid-level } \\
\text { management and involved leaders influences the routinization pro- } \\
\text { cess (GREENHALGH, ROBERT, MACFARLANE et al., 2004). Borins (2001) } \\
\text { concluded on his research that innovation on public services does not } \\
\text { originate, in essence, from the political sphere, but from the technical } \\
\text { workers within the organization's operational ranks. }\end{array}$ & $\begin{array}{l}\text { Greenhalgh, Robert, Macfarlane } \\
\text { et al. (2004); Damanpour and } \\
\text { Schneider (2008); Walker, } \\
\text { Damanpour and Devece (2010). }\end{array}$ \\
\hline & $\begin{array}{l}\text { Inter and intra- } \\
\text { organizational } \\
\text { communication in } \\
\text { networks }\end{array}$ & $\begin{array}{l}\text { The diffusion of innovation is influenced by social networks within the } \\
\text { organization and between organizations. Horizontal networks, for exam- } \\
\text { ple, favor communication between peers, whereas vertical networks } \\
\text { favor transmission between different levels (GREENHALGH, ROBERT, } \\
\text { MACFARLANE et al., 2004). }\end{array}$ & $\begin{array}{l}\text { Rogers (1983); Valente (1996); } \\
\text { Greenhalgh, Robert, Macfarlane } \\
\text { et al. (2004). }\end{array}$ \\
\hline & Ability to take risks & $\begin{array}{l}\text { The ability to take risks will determine the possibility of an innovation } \\
\text { being assimilated, given that, as safe as it may seem to be, there is } \\
\text { always a degree of uncertainty in innovations (GREENHALGH, ROBERT, } \\
\text { MACFARLANE et al., 2004). }\end{array}$ & $\begin{array}{l}\text { Greenhalgh, Robert, Macfarlane } \\
\text { et al. (2004); Brown (2010); Brown } \\
\text { and Osborne (2013). }\end{array}$ \\
\hline & $\begin{array}{l}\text { Organizational learning } \\
\text { / knowledge }\end{array}$ & $\begin{array}{l}\text { Learning process, which involves both the organizational scope and } \\
\text { the inter-organizational scope, is considered to be fundamental for the } \\
\text { improvement of public services (RASHMAN, WITHERS and HARTLEY, } \\
\text { 2009). Greenhalgh, Robert, Macfarlane et al. (2004) mention the capa- } \\
\text { city to absorb new knowledge as a systematically organizational capacity. }\end{array}$ & $\begin{array}{l}\text { Hartley and Benington (2006); } \\
\text { Hartley and Rashman (2007); } \\
\text { Rashman, Withers e Hartley (2009); } \\
\text { Hartley (2016). }\end{array}$ \\
\hline \multirow{4}{*}{ 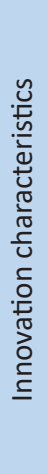 } & Adaptation/reinvention & $\begin{array}{l}\text { The innovation's capability of adapting to local contexts (GREENHALGH, } \\
\text { ROBERT, MACFARLANE et al., 2004). }\end{array}$ & $\begin{array}{l}\text { Rogers (1983); Greenhalgh, Robert, } \\
\text { Macfarlane et al. (2004). }\end{array}$ \\
\hline & Complexity & $\begin{array}{l}\text { Corresponds to the degree of difficulty that potential adopters had to } \\
\text { understand the innovation (ROGERS, 1983). }\end{array}$ & $\begin{array}{l}\text { Rogers (1983); Greenhalgh, Robert, } \\
\text { Macfarlane et al. (2004); De Vries, } \\
\text { Bekkers and Tummers (2016). }\end{array}$ \\
\hline & Relative advantage & $\begin{array}{l}\text { Indicator resulting from the evaluation of innovation compared to what } \\
\text { was previously in force and has been replaced. The advantage may be } \\
\text { organizational, economic and/or social, for example, and indicates the } \\
\text { superiority of innovation (ROGERS, 1983). }\end{array}$ & $\begin{array}{l}\text { Rogers (1983); Greenhalgh, Robert, } \\
\text { Macfarlane et al. (2004); De Vries, } \\
\text { Bekkers and Tummers (2016). }\end{array}$ \\
\hline & Compatibility & $\begin{array}{l}\text { According to Rogers }(1983, \text { p. } 15) \text {, it refers to "the degree in which an } \\
\text { innovation can be perceived as consistent in relation to existing values, } \\
\text { past experiences and the need for potential adopters." }\end{array}$ & $\begin{array}{l}\text { Rogers (1983); Greenhalgh, Robert, } \\
\text { Macfarlane et al. (2004); De Vries, } \\
\text { Bekkers and Tummers (2016). }\end{array}$ \\
\hline
\end{tabular}

Source: Elaborated by the authors. 


\section{METHODOLOGY}

This study adopts a qualitative approach in relation to its purposes (BAUER and GASKELL, 2017) to empirically test and describe the manifestation of the dimensions and variables that explain the diffusion of innovation in public services summarized in the presented theoretical model. For this, we mobilized two main sources of evidence collection: 1) institutional documents, submitted to documentary analysis; and 2) reports of specialists responsible for applying objective criteria in the selection of cases, which were obtained through interviews. For the documentary analysis, we requested the Awards' managing committee, at Enap itself, to access institutional documents linked to the Awards, such as the internal normative instruments and those related to the competition.

For the collection of reports that could represent the view of the specialists, we have selected members of the Enap Awards' external evaluation committee, that consists of senior public workers, scholars and consultants with expertise on public service innovation (CAVALCANTE, CAMÕES, CUNHA et al., 2017), in order to investigate their impressions on diffusion of innovation, in addition to the objective evaluation criteria and orientations given by Enap. We conducted interviews using a semi-structured research script (RICHARDSON, PERES, WANDERLEY et al., 1999), with the purpose of providing the respondent with narrative freedom, but using the key factors related to the diffusion of innovation as a basis. The interview script was divided into four blocks: 1) identification of the respondent and of their experience in evaluating innovation; 2) characterization of the performance of the respondent as external evaluator for the Award on innovation in the Public Sector; 3) evaluation criteria for the experiences participating in the Awards; and 4) the evaluators' degree of knowledge on the terminology and concepts related to innovation in public services and the diffusion of innovation. The interviews were conducted with 5 experts who composed the Technical Committee of the 20th edition of the Awards (2015), from October to December 2017 with 5 experts who composed the Technical Committee of the 20th edition of the Competition (year 2015). We describe their profile in Box 3.

\section{Box 3}

\section{Respondent profile}

\begin{tabular}{|c|l|}
\hline Respondent 1 & $\begin{array}{l}\text { Education / Current Position } \\
\text { Execialist on Public Policies and on Governmental Management who acts as coordinator at the } \\
\text { Executive for Studies and State Policies at the Applied Economic Research Institute (Ipea). }\end{array}$ \\
\hline Respondent 2 & $\begin{array}{l}\text { Has a PhD on Organizational and Labour Psychology. Adjunct Professor at the University of Brasilia } \\
\text { (UnB), acts as a Special Assistant to the Attorney General at the Federal Prosecution System. }\end{array}$ \\
\hline Respondent 4 & $\begin{array}{l}\text { Has a master's degree on Economy and acts as Head of the Brasilia's office of the UN's Economic } \\
\text { Commission for Latin America and the Caribbean (Cepal). }\end{array}$ \\
\hline Respondent 5 & $\begin{array}{l}\text { Project Management Specialist at the Brazilian Agency for Industrial Development (ABDI), linked to } \\
\text { the Ministry of Economy. }\end{array}$ \\
\hline
\end{tabular}

Source: Elaborated by the authors.

In order to approach the evidences obtained in the reports and in the documents, we adopted the Content Analysis proposed by Bardin (2009). For that, we initially defined three analysis categories (FLICK, 2004), representing the dimensions and variables summarized in the theoretical model, presented in Box 2. Thus, the empirical manifestations of two dimensions that explain the diffusion of innovation in public services are tested: 1) Characteristics of the organization (composed of 6 variables) and 2) Characteristics of the innovation (composed of 4 variables).

\section{CONTENT ANALYSES FOR DOCUMENTS AND REPORTS}

We now present the analyses according to the three thematic categories initially defined: 1) the role of diffusion on the diagnose of innovation in public services; 2 ) the role of the variables that explain the diffusion of innovation in public services within the Enap Awards; and 3) the limitations of the methodology used in the Enap Awards on Innovation in Public Services. 


\section{The role of diffusion on the diagnose of innovation in public services}

This category maps the experts' perception of the role played by diffusion in the innovation process analysed by Enap. When asked about how diffusion is considered in this process, only part of the experts consider that it is already considered, although subjectively. Among the 5 specialists, 2 are not familiar with the concept or the importance of diffusion. Among those who identify diffusion as a critical stage of innovation, the Schumpeterian function (SCHUMPETER, 1985, 2017) of diffusion is evidenced as a confirmatory step of innovation (in the report, expressed in terms of "institutionality") and value of exchange associated with an innovative practice as a requirement for its diffusion, also a premise associated with Schumpeterian competition. One respondent mentions that diffusion is important for the knowledge transfer process and "eventually also to innovation."

\section{Box 4}

Lines on the role of diffusion in the innovation process

\begin{tabular}{|c|c|}
\hline Respondents & Lines \\
\hline E1 & $\begin{array}{l}\text { An innovation only gets consolidated when it gains institutionality, in the case of public administration, } \\
\text { this is particularly critical. Public administration is, by nature, highly regulated and very hierarchical, so it } \\
\text { is often the case that legal and normative aspects are critical points for an innovation to happen or not. }\end{array}$ \\
\hline E2 & $\begin{array}{l}\text { I have no knowledge on the literature about management, innovation, I work more in the dimensions of } \\
\text { productivity, externalities, economy of scale, microeconomic studies than essentially with administration } \\
\text { in organizations. Diffusion is a time-based issue because, in an innovation award, you look for novelty, so } \\
\text { things that should not yet have much history of diffusion. }\end{array}$ \\
\hline E3 & $\begin{array}{l}\text { I believe so, and diffusion, it will gain scope, strength when results are presented and are appreciated, } \\
\text { then, as far as we identify, within the organization, that it has an advantage and a cost-benefit in adhering } \\
\text { to a specific practice or that it is more worthwhile than a current practice. Some North-American studies } \\
\text { on diffusion have shown this much, from the moment that Municipalities or States show positive results } \\
\text { from a given public policy, others tend to replicate, tend to adhere, then, the stage in which the diffusion is } \\
\text { practiced the most is after the results are recognized by a larger group, outside of the organizational scope. }\end{array}$ \\
\hline E4 & $\begin{array}{l}\text { Diffusion is important to any learning or knowledge transference process, and eventually also to innovation. } \\
\text { Diffusion became fundamental today, during the knowledge society in the digital era, the more we manage } \\
\text { to share and diffuse, the more we can create even improvements to the diffused process itself, as the others } \\
\text { replicate l, this continues to improve, this is the process of continuous improvement itself, it ensures the } \\
\text { improvement process itself. }\end{array}$ \\
\hline E5 & $\begin{array}{l}\text { I believe in the existence of a series of "main elements" that consolidate the innovation in the public sector, } \\
\text { and "diffusion" is certainly among them. However, there are others of equal importance, such as creating } \\
\text { results, efficiency, sustainability and organizational impact. }\end{array}$ \\
\hline
\end{tabular}

Source: Elaborated by the authors.

When analysing the criteria presented by the candidate's manual for the 21st edition of the Awards (2016), the following grade weights were used to select cases: a) innovation (weight 3); b) results and/or impacts (weight 2); c) efficient use of resources (weight 1); d) partnerships (weight 1); e) participation of the beneficiaries (weight 1); f) transparency and social control mechanisms (weight 1); g) degree of replicability (weight 1); and h) degree of sustainability (weight 1).

For the "innovation" criterion (weight 3), according to Ferrarezi, Amorim and Tomacheski (2010), the Awards have selected the concept of innovation as the development and implementation of changes to previous practices, based in the incorporation of new elements to the public administration or a new combination of pre-existent elements, capable of producing results to both the public service and the society. This way, the concept of innovation itself and, consequently, the "innovation" criterion used by Enap takes into consideration the conceptual and terminological repertoire of the diffusion of innovation, albeit in part. The concepted adopted by the Awards considers the novelty in relation to the previous situation, the implementation of the change and the results achieved. According to the specialists, this criterion essentially analyses the relative advantage characteristic of innovation, that is, the characterization of the advantage brought by innovation in relation to what had prevailed and has been replaced. In terms of diffusion, this way the direct way of diagnosing has been limited to the characterization of the relative advantage over the previous process or service. Therefore, the incorporation of criteria for detecting the dissemination of the processes or services analysed in the cases is lacking. 
Terms such as "sustainability" and "replicability" are used within the Awards' criteria in different conceptual approaches that could be related to the theory of diffusion of innovation. The review of the literature, for example, leads us to the use, in public management research, of terms such as "administrative continuity" (NOGUEIRA, 2006), alongside the term "sustainability", which, besides not being a universal term for the diffusion of innovation, as recognized by the study by Greenhalgh, BartonSweeney and Macfarlane (2013), which in its review of the literature includes the terms institutionalization and routinization, can also indicate the discussion about socio-environmental sustainability, of major interest in the present time and which is described with such inference in the candidate's manual. The degree of sustainability, according to the candidate's manual,

[...] measures the impact of the initiative's actions and results on both the society and the environment. The criterion considers the sustainable development under an integrative perspective, in which the human well-being and the environmental and social factors are interdependent elements (ENAP, 2016, p. 17).

The criterion, although it seems in line with the terminology of diffusion, does not refer to the institutionalization (ALBERTI and BERTUCCI, 2006) or to the routinization (GREENHALGH, ROBERT, MACFARLANE et al., 2004) of innovation.

\section{The role of the variables that explain the diffusion of innovation in public services within the Enap Awards}

During the interviews, we invited the specialists to give their opinion on the role played by each of the variables associated with the two theoretical dimensions that explain the diffusion of innovation in public services in the context of the Enap Awards. These results, their discussions and their reflections on the theory are summarized in Box 5.

\section{Box 5}

The role of the variables that explain the diffusion of innovation in public services within the Enap Awards

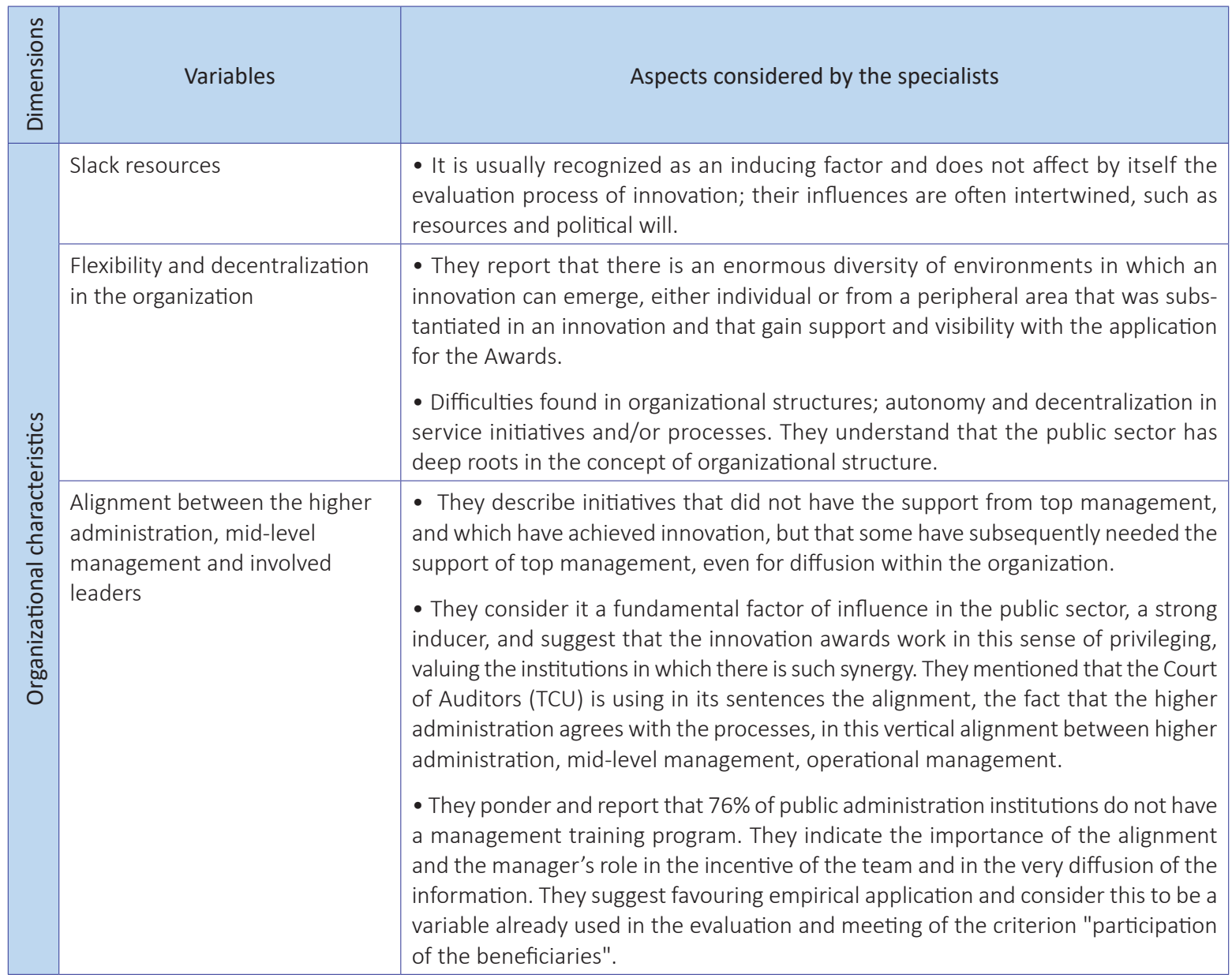




\begin{tabular}{|c|c|c|}
\hline 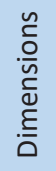 & Variables & Aspects considered by the specialists \\
\hline \multirow{3}{*}{ 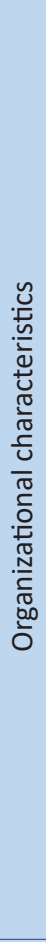 } & $\begin{array}{l}\text { Inter and intra-organizational } \\
\text { communication in networks }\end{array}$ & $\begin{array}{l}\text { - They consider a relevant factor and report that the most successful experiences in } \\
\text { the evaluation of the awards were those that achieved good inter and intra-organi- } \\
\text { zational communication or that predicted communication strategies. } \\
\text { - They consider that communication is a relevant factor in the contemporary world, } \\
\text { and that the organization or individual needs to sell the idea, in fact, to sell the change. }\end{array}$ \\
\hline & Ability to take risks & $\begin{array}{l}\text { - Respondents report that this variable can create a comparison problem. The inno- } \\
\text { vation often occurred because it was restricted, that is, its occurrence represented } \\
\text { a low organizational risk. For example: "I remember incredible, very good cases in } \\
\text { which the budget cost was zero, that is, for the organization it was a very small risk, } \\
\text { and now projects, some projects, they are already born large, they are born, for } \\
\text { example, with the pretension of reaching the whole organization and then you need } \\
\text { to develop this theme, you need to buy equipment, then you have costs and some- } \\
\text { times you will make the change within the whole organization, with the enormous } \\
\text { risk of having a problem, then this is a problem that involves the following situation } \\
\text { for the awards, smaller projects, pilots, restricted things have a higher chance to } \\
\text { succeed, to be implemented, and to make a good figure in the awards, while big pro- } \\
\text { jects face enormous difficulties of risk, of available resources and even of complexity". }\end{array}$ \\
\hline & $\begin{array}{l}\text { Organizational learning / } \\
\text { knowledge }\end{array}$ & $\begin{array}{l}\text { - The specialists indicate that there could be more studies on this variable, since } \\
\text { the relation between innovation, training results and knowledge systematization } \\
\text { is recognized. They deliberate that it is an interesting aspect to be emphasized in } \\
\text { innovation evaluation. } \\
\text { - They consider it as an inductor to which a reference is made as soon as in the } \\
\text { evaluation for the awards. }\end{array}$ \\
\hline \multirow{4}{*}{ 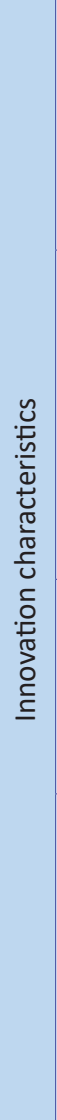 } & Adaptation/reinvention & $\begin{array}{l}\text { - They consider that an innovative initiative often requires a kind of revision over } \\
\text { time. Thus, they understand that replications are processes in which innovation is } \\
\text { revisited in the light of another reality, so they consider experiences with greater } \\
\text { potential for dissemination to be more interesting, that is, adapted experiences, } \\
\text { until redesigned, an improved version appears. } \\
\text { - They consider it a factor for sustainability. }\end{array}$ \\
\hline & Complexity & $\begin{array}{l}\text { - They differentiate this factor from the perspective of incremental innovations } \\
\text { with a lower degree of complexity. In the case of a radical innovation, it can have } \\
\text { greater complexity. } \\
\text { - They mention that a complex innovation either demands greater efforts or beco- } \\
\text { mes more difficult to be assimilated or implemented, especially in the public sector. } \\
\text { A more complex initiative can have a disadvantage when compared to another, but } \\
\text { not on its impacts. It requires more from its formulators and implementers. There } \\
\text { is an enormous effort of analysis, elaboration and understanding of the reality. }\end{array}$ \\
\hline & Relative advantage & $\begin{array}{l}\text { - It is a common view among the respondents that relative advantage is the most } \\
\text { recurring factor of influence in the evaluation, since it evaluates the change brought } \\
\text { by the initiative in relation to the previous reality, the substantial improvement. } \\
\text { - They understand that this characteristic can subsidise improvements to the set of } \\
\text { indicators that is used in the evaluation for the awards. }\end{array}$ \\
\hline & Compatibility & $\begin{array}{l}\text { - They consider that the contest currently values innovations implemented. If they } \\
\text { consider initiatives that have not yet been implemented, they suggest that compa- } \\
\text { tibility is considered a key variable to assess the consistency of innovation. } \\
\text { - They differentiate this factor from the perspective of incremental innovations with } \\
\text { a higher degree of compatibility: "in the case of a radical innovation, it may have } \\
\text { less compatibility, it may be an indicator that needs to be evaluated, which measure- } \\
\text { ment, how are we going to propose the implementation of such innovation, because } \\
\text { this compatibility issue is an important factor." }\end{array}$ \\
\hline
\end{tabular}

Source: Elaborated by the authors. 


\section{Limitations of the methodology used in the Enap Awards on Innovation in Public Services}

Finally, this study sought to identify what are the limitations of the methodology of evaluation of innovative experiences adopted until then by Enap under the evaluators' perception. These results are represented by the selected statements (Box 6). The understanding is that the reports of the cases, provided by the candidates themselves, limit the collection of accurate and potentially valuable information to the evaluators.

Another relevant limitation refers to the difficulty of evaluating objective performance criteria, in order to deal with newly implemented innovations. This is a limitation that can be overcome, albeit partially, by adopting the explanatory variables of diffusion listed in the theoretical model presented in this study. For example, when evaluating the degree of complexity of an innovation, even if recently implemented, one can have objective indicators about its potential for diffusion and, thus, one can have indicators of impact potential - the one indicator sought by Enap. We therefore recommend the incorporation of indicators associated to the diffusion diagnosis to the criteria used by Enap as a strategy to measure impact potential, the greatest limitation identified by the experts.

\section{Box 6}

Limitations of the evaluation methodology used for innovative experiences

\begin{tabular}{|c|c|}
\hline Respondents & Lines \\
\hline E1 & $\begin{array}{l}\text { "The main, and this has been discussed a few times, is that we don't have real conditions for a more } \\
\text { concrete knowledge about each applicant experience, I mean, information is based on reports prepared by } \\
\text { the candidates themselves, and those reports are, in general, not well elaborated, and also there is another } \\
\text { mechanism that is the technical visit, that also presents reports. However, those resources sometimes are } \\
\text { not sufficient, then this is a limitation, and it is necessary to know a great amount of experiences and to } \\
\text { compare them, the workload for the evaluator is huge, and the timeframe is restricted, then those are the } \\
\text { limitations that difficult the expansion of the knowledge about the experiences. However, I do not consider } \\
\text { them to be grave limitations or that they could compromise the proposal." }\end{array}$ \\
\hline E2 & $\begin{array}{l}\text { "The evaluation methodology has always the question of the impact being the great criterion, it is very } \\
\text { difficult to have indicators of this, so we cannot evaluate if an initiative has effectively changed the trajectory } \\
\text { of a program, a service or an attendance, then the evaluation goes much more towards the novelty and } \\
\text { the capacity for impact, and also for the ease of adoption." }\end{array}$ \\
\hline E3 & $\begin{array}{l}\text { "The limitations regarding the evaluation methodology for the experiences are a lot related to the concept } \\
\text { of innovation itself, there is a high level of subjectivity in the concept of innovation in the private sector, bur } \\
\text { especially in the public sector, since innovation is an idea implemented that generate results and, in the } \\
\text { public sector, in several cases such results cannot be measured like profit, market share, etc." }\end{array}$ \\
\hline E4 & $\begin{array}{l}\text { "In the source of evaluation, improvement to get more trustworthiness, a higher reliability in the evaluation, } \\
\text { but I think that's it, it's going to have to be always improved". }\end{array}$ \\
\hline E5 & $\begin{array}{l}\text { "Every methodology has limitations. I believe that the Award's methodology has substantially evolved through } \\
\text { the editions. However, some problems naturally remain, including;(1) there are some criteria that are more } \\
\text { subjective, such as those related to sustainability of the proposals or to the degree of participation of the } \\
\text { people involved, which make their applicability a lot different among the evaluators; (2) the evaluation } \\
\text { concept itself is extremely broad and flexible, maybe in the future a possibility would be to segment the } \\
\text { awards according to the nature of the presented cases, or even according to the expected impact degree; } \\
\text { (3) a third methodological issue is the presentation of the report, not always the methodology can help } \\
\text { with the accurate representation of all the details of the concrete experience through a written report, } \\
\text { sometimes the field visits are important, maybe they should increase theirfrequency and their importance } \\
\text { for the whole process." }\end{array}$ \\
\hline
\end{tabular}

Source: Elaborated by the authors. 


\section{CONCLUSIONS}

This study aimed to map dimensions and variables that could explain the diffusion of innovation in public services and to test their applicability to the Enap Awards case. In relation to the perception of the role of diffusion in diagnosing innovation in public services, only two of the specialists demonstrate having theoretical knowledge about the nature of the diffusion process and its real meaning while a confirmatory stage of innovation. The other specialists recognize it as a factor "among others of the same importance" or as a factor that depends of a "time question" and, for that reason, nor a priority for an award on innovation, naturally oriented for detecting novelty. When applied to the award's objective criteria, the concept of diffusion limits itself to detecting the relative advantage in relation to the process or service previously adopted. Therefore, it is revealed that so far Enap's understanding is limited to the detection of an immediate relative advantage.

Regarding the manifestation of the variables that explain diffusion under the specialists' perception, it is reported that the two dimensions and all of their 10 associated variables were recognized and typified by the specialists, what confirmed the applicability of the theoretical dimensions to the Enap Awards case. Some of the variables, such as "ability to take risks", have their own manifestation different form that expressed by the theory - a premised that must be considered in a future operationalization of the model. Thus, we understand that the theoretical model tested in this study must primarily incorporate the fact that innovation in public services can occur in environments with low organizational risk levels, unlike what one would expect, precisely because it would involve low budgetary risk, for example.

The study also allowed to characterize the limitations of the evaluation methodology previously adopted by Enap. The dilemma of having to diagnose impact indicators for newly adopted innovations reported by their own creators, often without unified criteria, is highlighted by the evaluators. In this sense, we understand that the explanatory variables of the theoretical model summarized in this study may be useful to Enap as a strategy to measure the impact potential of innovations that compete for the award, the greatest limitation identified by the experts. Thus, it is recommended that Enap incorporate in its future evaluations for the cases to be awarded the following variables associated to the diffusion of innovation manifest in this study: Slack resources, Flexibility and decentralization in the organization, Alignment between the higher administration, mid-level management and involved leaders, Inter and intra-organizational communication, Ability to take risks, Organizational learning / knowledge, Innovation adaptation/reinvention, Innovation complexity, Relative advantage, Innovation compatibility.

From this study, a research agenda is set up to fill the following gaps: 1) to propose the operationalization of the explanatory theoretical variables in the form of objective criteria that can be used to diagnose diffusion potential for innovations in public services; 2 ) to develop studies that identify the sustainability process as routinization and institutionalization in the organizational sphere as a strategy for the diffusion of innovation in the public sector; 3 ) to apply the variables that explain the diffusion of innovation to real public services cases in order to test their manifestation and ability to represent reality in different organizational contexts. Among the limitations of this study, it is worth mentioning the access to the specialists, who are a small and confidential population. 


\section{REFERENCES}

ALBURY, D. Fostering innovation in public services. Public Money and Management, v. 25, n. 1, p. 51-56, 2005.

ALBERTI, A.; BERTUCCI, G. (Org.). Innovations in governance and public administration: replicating what works. New York: United Nations, 2006.

BARDIN, Laurence. Análise de conteúdo. Lisboa: Edições 70, 2009.

BAUER, M. W.; GASKELL, G. Pesquisa qualitativa com texto, imagem e som: um manual prático. Petrópolis: Vozes, 2017.

BLOCH, C. Towards a conceptual framework for measuring public sector innovation. Nordic project 'Measuring innovation in the public sector in the Nordic countries: toward a common statistical approach' (“Copenhagen Manual"). [s.l.]: [s.n.], 2010.

BORINS, S. Encouraging innovation in the public sector. Journal of Intellectual Capital, v. 2, n. 3, p. 310-319, 2001.

BORINS, S. The persistence of innovation in government. Washington, DC: Brookings Institution Press/Ash Center for Democratic Governance and Innovation, 2014.

BRESSER-PEREIRA, L. C. A reforma gerencial do Estado de 1995. Revista de Administração Pública, Rio de Janeiro, v. 34, n. 4, p. 7-26, 2000.

BROWN, L. Balancing risk and innovation to improve social work practice. British Journal of Social Work, v. 40, n. 4, p. 12111228, 2010.

BROWN, K.; OSBORNE, S. P. Managing change and innovation in public service organizations. New York: Routledge, 2012.

BROWN, L.; OSBORNE, S. P. Risk and innovation: towards a framework for risk governance in public services. Public Management Review, v. 15 , n. 2, p. 186-208, 2013.

CAVALCANTE, P. et al. (Org.). Inovação no setor público: teoria, tendências e casos no Brasil. Brasília, DF: Ipea/Enap, 2017.

DAMANPOUR, F. Organizational innovation: a meta-analysis of effects of determinants and moderators. Academy of Management Journal, v. 34, n. 3, p. 555-590, 1991.

DAMANPOUR, F.; SCHNEIDER, M. Phases of the adoption of innovation in organizations: effects of environment, organization and top managers. British Journal of Management, v. 17, n. 3, p. 215-236, 2006.

DAMANPOUR, F.; SCHNEIDER, M. Characteristics of innovation and innovation adoption in public organizations: assessing the role of managers. Journal of Public Administration Research and Theory, v. 19, n. 3, p. 495-522, 2008.

DAMANPOUR, F.; WALKER, R. M.; AVELLANEDA, C. N. Combinative effects of innovation types and organizational performance: a longitudinal study of service organizations. Journal of Management Studies, v. 46, n. 4, p. 650-675, 2009.

DE VRIES, H.; BEKKERS, V.; TUMMERS, L. Innovation in the public sector: a systematic review and future research agenda. Public Administration, v. 94, n. 1, p. 146-166, 2016.

DOSI, G. Mudança técnica e transformação industrial: a teoria e uma aplicação à indústria dos semicondutores. Campinas: Unicamp, 2005.
ESCOLA NACIONAL DE ADMINISTRAÇÃO PÚBLICA - ENAP. Edital Enap 15/2016. 2016. Available at: <https://inovacao.enap.gov.br/21oconcurso/edital/>. Accessed on: Mar. 31, 2018.

FARAH, M. F. S. Dissemination of innovations: learning from subnational awards programmes in Brazil. In: ALBERTI, A.; BERTUCCI, G. (Org.). Innovations in governance and public administration: replicating what works. New York: United Nations, 2006. p. 67-75.

FERRAREZI, E.; AMORIM, S. N. D.; TOMACHESKI, J. A. Sustentabilidade de iniciativas premiadas no concurso inovação: indícios de mudança da gestão no governo federal? Brasília, DF: Escola Nacional de Administração Pública, 2010. (Cadernos Enap, n. 34).

FLICK, U. As narrativas como dados. In: FLICK, U. Uma introdução à pesquisa qualitativa. Porto Alegre: Bookman, 2004. p. 109-123.

GALLOUJ, F.; SAVONA, M. Towards a theory of innovation in services: a state of the art. In: GALLOUJ, F.; DJELLAL, F. (Ed.). The handbook of innovation and services: a multi-disciplinary perspective. Cheltenham: Edward Elgar, 2010. p. 27-48.

GREENHALGH, T.; BARTON-SWEENEY, C.; MACFARLANE, F. Exploring the diffusion and sustainability of service innovation in healthcare. In: OSBORNE, S. P.; BROWN, L. (Ed.). Handbook of innovation in public services. Cheltenham: Edward Elgar, 2013. p. 540-562.

GREENHALGH, T. et al. Diffusion of innovations in service organizations: systematic review and recommendations. The Milbank Quarterly, v. 82, n. 4, p. 581-629, 2004.

HARTLEY, J. Organisational and governance aspects of diffusing public innovation. In: TORFING, J.; TRIANTAFILLOU, P. (Ed.). Enhancing public innovation by transforming public governance. Cambridge: Cambride University Press, 2016. p. 71-94.

HARTLEY, J.; BENINGTON, J. Copy and paste, or graft and transplant? Knowledge sharing through inter-organizational networks. Public Money and Management, v. 26, n. 2, p. 101-108, 2006.

HARTLEY, J; RASHMAN, L. How is knowledge transferred between organizations involved in change. In: WALLACE, M.; FERTIG, M.; SCHNELLER, E. (Eds.). Managing change in the public services. Malden: Blackwell, 2007. p. 173-192.

HOWELLS, J. Services and innovation and service innovation: new theoretical directions. In: GALLOUJ, F.; DJELLAL, F. (Ed.). The handbook of innovation and services: a multi-disciplinary perspective. Cheltenham: Edward Elgar, 2010. p. 68-83.

HUGHES, A.; MOORE, K.; KATARIA, N. Innovation in public sector organisations: a pilot survey for measuring innovation across the public sector. London: NESTA, 2011.

METCALFE, J. S.; MILES, I. (Ed.). Innovation systems in the service economy: measurement and case study analysis. Berlin: Springer Science \& Business Media, 2012.

MEYER, A. D.; GOES, J. B. Organizational assimilation of innovations: a multilevel contextual analysis. Academy of Management Journal, v. 31, n. 4, p. 897-923, 1988. 
MILES, I. Patterns of innovation in service industries. IBM Systems Journal, v. 47, n. 1, p. 115-128, 2008.

NOGUEIRA, F. A. Continuidade e descontinuidade administrativa em governos locais: fatores que sustentam a ação pública ao longo dos anos. $139 \mathrm{f}$. Master Thesis (Master Degree in Public Administration and Government) - Escola de Administração de Empresas de São Paulo, Fundação Getulio Vargas, São Paulo, 2006.

ORGANIZAÇÃO PARA A COOPERAÇÃO E DESENVOLVIMENTO ECONÔMICO - OCDE. Manual de Oslo. Diretrizes para coleta e interpretação de dados sobre inovação. Paris: OCDE, 2005.

RASHMAN, L.; WITHERS, E.; HARTLEY, J. Organizational learning and knowledge in public service organizations: a systematic review of the literature. International Journal of Management Reviews, v. 11, n. 4, p. 463-494, 2009.

RICHARDSON, R. J. et al. Pesquisa social: métodos e técnicas. 3. ed. São Paulo: Atlas, 1999.

ROGERS, E. M. Diffusion of innovation. New York: Free Press, 1983.

SCHUMPETER, J. A. Teoria do desenvolvimento econômico. Rio de Janeiro: Fundo de Cultura, 1985.

SCHUMPETER, J. A. Capitalismo, socialismo e democracia. São Paulo: Unesp, 2017.
SUGARHOOD, P. et al. Technology as system innovation: a key informant interview study of the application of the diffusion of innovation model to telecare. Disability and Rehabilitation: Assistive Technology, v. 9, n. 1, p. 79-87, 2014.

VALENTE, T. W. Social network thresholds in the diffusion of innovations. Social Networks, v. 18, n. 1, p. 69-89, 1996.

VAN DE VEN, A. H.; POLLEY, D.; GARUD, R. The innovation journey. Oxford: Oxford University Press, 2008.

WALKER, R. M. Innovation type and diffusion: an empirical analysis of local government. Public Administration, v. 84, n. 2, p. 311-335, 2006

WALKER, R. M. An empirical evaluation of innovation types and organizational and environmental characteristics: towards a configuration framework. Journal of Public Administration Research and Theory, v. 18, n. 4, p. 591-615, 2007.

WALKER, R. M. Internal and external antecedents of process innovation: a review and extension. Public Management Review, v. 16, n. 1, p. 21-44, 2014.

WALKER, R. M.; DAMANPOUR, F.; DEVECE, C. A. Management innovation and organizational performance: the mediating effect of performance management. Journal of Public Administration Research and Theory, v. 21, n. 2, p. 367-386, 2010.

Elisângela Dourado Arisawa

ORCID: https://orcid.org/0000-0002-8153-5933

Analyst at Instituto Nacional de Estudos e Pesquisas Educacionais Anísio Teixeira - INEP; Master in Public Administration from the Graduate Program in Administration- PPGA/UnB, Brasília-DF, Brazil. E-mail: elisangela.dourado@gmail.com

Marina Figueiredo Moreira

ORCID: https://orcid.org/0000-0001-5052-3975

Post-doctorate in Business from the University of Nottingham (UK) and PhD in Gestion Sciences from the Université Aix-Marseille (France); Coordinator of the Master of Public Administration-MPA/PPGA/UnB, Brasília- DF, Brazil. E-mail: marinamoreira.adm@gmail.com 